\title{
Selection of Functional Diagram of Air Multi-Compressor Control System
}

\author{
Roman Kokoshko*, Oleksandr Kril, Bohdan Kril \\ Lviv Polytechnic National University, 12 S. Bandera St., Lviv, 79013, Ukraine \\ Received: May 05, 2019. Revised: June 04, 2019. Accepted: June 11, 2019.
}

(C) 2019 The Authors. Published by Lviv Polytechnic National University.

\begin{abstract}
Compressed air generation systems are a necessary facility for most enterprises; they also belong to the most energy-consuming equipment category. Study of transients of these systems' operation is a prerequisite for creating new, more efficient algorithms of multi-compressor control systems. The paper presents the results of development and research of the operation algorithms of multi-compressor control systems. It is proposed that major solutions for the start/shutdown of specific compressors and changing their productivity should be implemented on a programmable logic controller that will function as the master for the local controllers of the individual compressors. A high-speed flow meter based on the differential pressure method for measuring the air flow-rate has been developed and implemented. The flow meter provides an auxiliary informative signal.
\end{abstract}

Keywords: multi-compressor system; compressor; compressed air; programmable logic controller; variablefrequency drive.

\section{Introduction}

Compressed air is an important source of energy in modern production environments. It is used for driving into action various pneumatic actuating mechanisms such as pneumatic cylinders, isolation and control valves and gates, vibrators, etc. The advantages that such mechanisms offer are the high speed and strong force combined with the small size and simple structure. They are suitable for use in explosive environments. Compressed air is also used as a reactant in technological oxidation, fractionation, cooling, filtering, blowing, drying and aeration. Table 1[1] presents the list of the main industries that widely use compressed air.

In general, each of the production processes listed in Table 1 uses at least two medium-power air compressors (from 30 to $600 \mathrm{~kW}[7,8]$ ) or more. As the production capacity rises, the need for compressed air grows, which results in the increasing number of compressor systems. When two or more compressors are used, the system is called a multi-compressor system [3].

The process of such reconstruction can be quite lengthy, and as a result of the production modernization, the compressor equipment may consequently consist of units differing in power, production date and manufacturer. This is not a major drawback, as the productivity of such multi-compressor systems resulting from the production increase should be able to change in a flexible way depending on the air consumption, the number of pieces of technological equipment used and its productivity. However, an important task that arises is an effective control of such a multi compressor system, which consists in minimizing the energy losses and reducing the number of turn ons and offs of specific compressor units. The loss of control of a multi-compressor system is referred to as control gap, and it is discussed in [3].

\footnotetext{
"Corresponding author. Email address: r.kokoshko151@gmail.com
}

This paper should be cited as: R. Kokoshko, O. Kril, B. Kril. Selection of functional diagram of air multicompressor control system. Energy Engineering and Control Systems, 2019, Vol. 5, No. 1, pp. 47 - 56. https://doi.org/10.23939/jeecs2019.01.047 
Table 1. Industries using the compressed air.

\begin{tabular}{|c|c|}
\hline Clothing industry & Conveying, clamping, tool powering, controls and actuators, automated equipment \\
\hline Automotive industry & Tool powering, stamping, control and actuators, forming, conveying \\
\hline Chemicals & Conveying, controls and actuators \\
\hline Food production & Dehydration, bottling, controls and actuators, conveying, spraying coatings, cleaning, vacuum packing \\
\hline Furniture & Air piston powering, tool powering, clamping, spraying, controls and actuators \\
\hline General Manufacturing & Clamping, stamping, tool powering and cleaning, control and actuators \\
\hline Lumber and Wood & Sawing, hoisting, clamping, pressure treatment, controls and actuators \\
\hline Metals Fabrication & Assembly station powering, tool powering, controls and actuators, injection molding, spraying \\
\hline Petroleum & Process gas compressing, controls and actuators \\
\hline Primary Metals & Vacuum melting, controls and actuators, hoisting \\
\hline Pulp and Paper & Conveying, controls and actuators \\
\hline Rubber and Plastics & Tool powering, clamping, controls and actuators, forming, mold press powering, injection molding \\
\hline Stone, Clay and Glass & Conveying, blending, mixing, controls and actuators, glass blowing and molding, cooling \\
\hline Textiles & $\begin{array}{l}\text { Agitating liquids, clamping, conveying, automated equipment, controls and actuators, loom jet weaving, } \\
\text { spinning, texturizing }\end{array}$ \\
\hline
\end{tabular}

According to [10], the energy costs make up more than $75 \%$ of the life-cycle costs of an air compressor (Fig. 1).

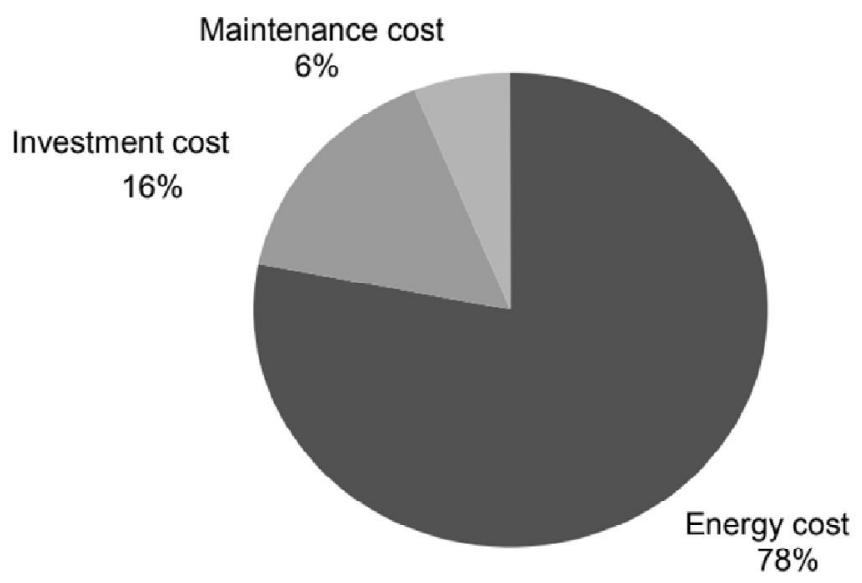

Fig.1. Life-cycle cost structure for an air compressor.

For energy-efficient operation of air compressors, a variety of methods of control and organization of their operation can be used, and one of the most effective is maintaining the compressed air pressure in the system at a level slightly exceeding a set-point value [7,11]. However, this method of multi-compressor system control requires an accurate regulation of the pressure and smooth switching of the compressors in order to reduce pressure swings in the system.

Today, enterprises mostly use rotary screw compressors [7,8], lubricant-injected or lubricant-free (when the compressed air is used in direct contact with a product). These compressors are often equipped with frequency converters for a smooth regulation of productivity. Frequency converters in air multi-compressor systems not only provide for increasing the energy efficiency, but they also meet the need for a smooth regulation of productivity with minimum swings of the compressed air pressure in the system.

\section{General characteristic of the variable load of compressed air consumption}

When compressed air is used in a production environment for cooling, at product discharge or at selection of large-volume buffer capacity, the instantaneous compressed air flow surges. Such processes in a large production 
environment can be concurrent or occur separately, but the multi-compressor system is supposed to be responsive to the change of pressure and flow-rate in the system and maintain the compressed air pressure within the set range. Therefore, such systems are assigned to variable load systems, in which compressed air flow-rate can double in a few seconds; the increase in this value can be even more drastic. For instance, Fig. 2 presents the historical trend of the air demand variation in a brewery environment.

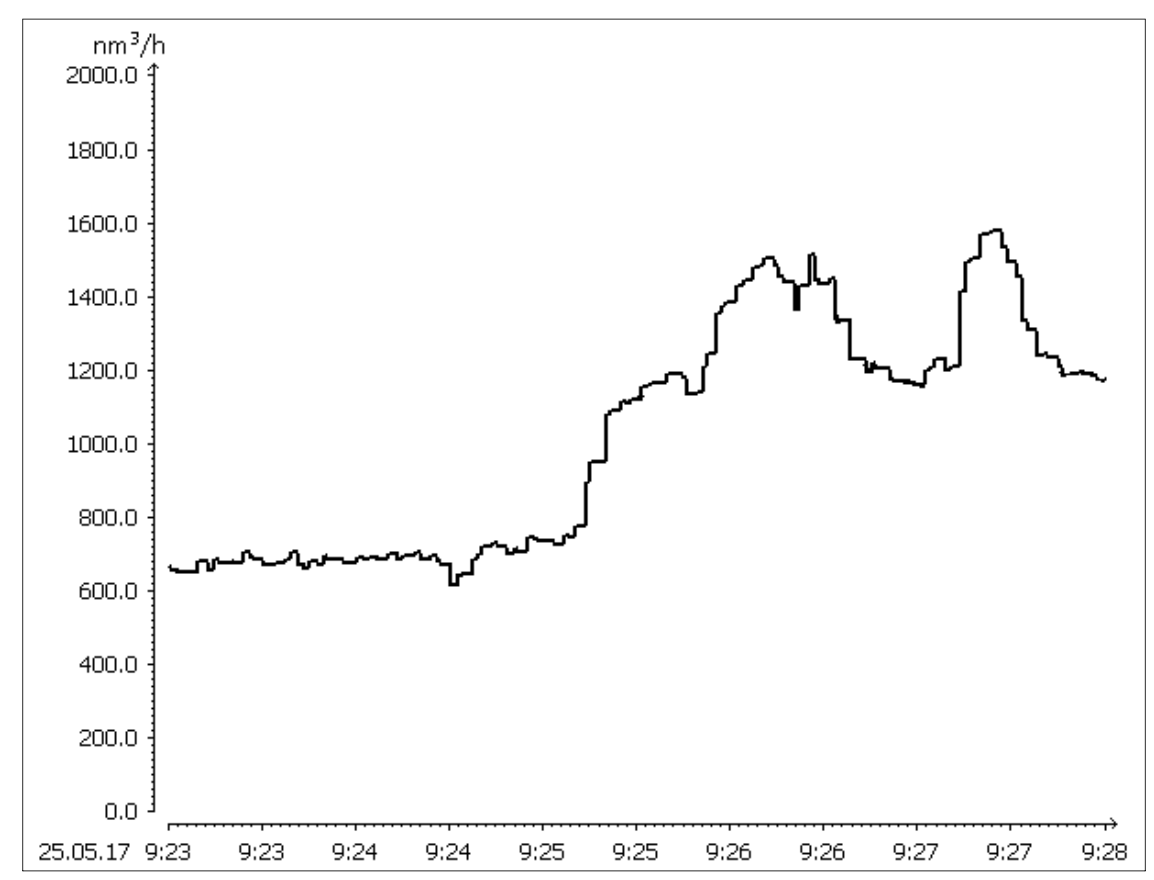

Fig.2. Historical trend of the air flow-rate variation at Carlsberg Ukraine PJSC, Lviv Brewery.

To ensure energy-efficient operation of air compressors, it is recommended that the main master controller should be used in multi-compressor systems for selecting and turning on/off compressors with needed productivity in order to ensure a stable value of the compressed air pressure in case of a drastic change of the flow-rate [7,11].

Modern industry widely uses programmable logic controllers, which make it possible to input informative signals from pressure, temperature and flow sensors. Data is collected in one place and then transferred to the highlevel control. Programmable logic controllers support different data transfer protocols, which is convenient for building a fieldbus.

Therefore, the formulation of principles and algorithms of specific compressors' control in a multi-compressor system is of topical importance.

\section{Building control systems for fixed-speed compressor systems}

Modern compressors are equipped with individual control systems, which control them depending on a fixed setpoint pressure value or a certain set-point pressure range. Rotary screw compressors operate in three modes [7]: load (the mode in which the compressor works and creates a set pressure in the system), unload (the mode in which the compressor works but does not create pressure in the system) and standby (the mode in which the compressor does not work but awaits a start signal).

In the unload mode, the compressor consumes $15-35 \%$ [3] of the energy consumed at the full productivity, which is why a continuous operation of the unit in the unload mode decreases the general energy efficiency of the multicompressor system.

For the control of a multi-compressor system consisting of several fixed-speed compressors, a so-called cascade control system is used. In such a system, each individual control system has its specific range of pressure values set up for it, upon reaching which this compressor starts. When the upper limit of the range is reached, the 
compressor switches into the unload mode, and if the pressure does not decrease, the compressor switches into the stand-by mode (Fig. 3).

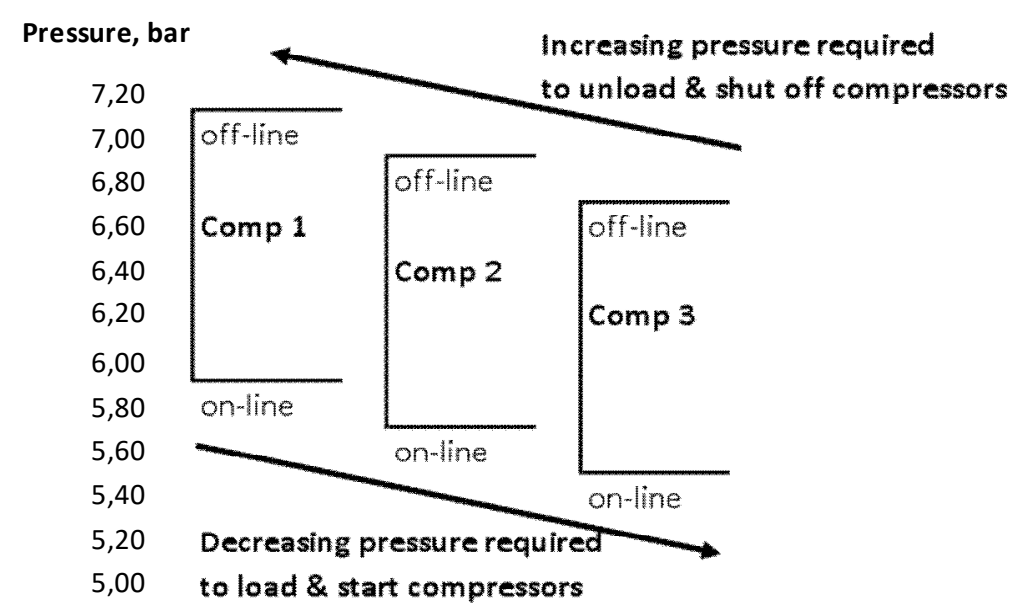

Fig.3. Cascade control algorithm for a fixed-speed multi-compressor system.

\section{Control systems for variable-speed compressor systems}

When using frequency converters in compressor control systems, it is necessary to select an appropriate compressor whose drive will be powered from the frequency converter. As shown in [3], a wrong choice of variableload compressor results in the operation of two or more compressors; thereat, the fixed-speed compressors continuously switch from the load mode into the unload mode, and the variable-speed compressor operates in the oscillatory mode. Therefore, when selecting a compressor supposed to operate at a variable rotation speed of the drive in order to change the productivity, one should consider whether it will provide for at least the minimum required compressed air flow-rate. This is due to the fact that compressor manufacturers specify the minimum permissible motor rotation speed allowing continuous operation of the compressor. At a continuous operation of such a compressor with a frequency converter at the maximum productivity, the electricity consumption will exceed that for a similar fixed-speed compressor. This stems from the energy conversion efficiency of the frequency converter and additional losses at the motor caused by the eddy currents, and these losses are often underestimated. According to [2], the most efficient operation of variable-speed compressors is achieved at up to $80 \%$ of their maximum productivity. Thereat, as shown in [11], for variable-speed compressors the most efficient operation in air multicompressor systems is ensured for the operation in the maximum productivity mode.

The simplest control system for a variable-load compressor based on a programmable logic controller using a frequency converter is shown in Fig. 4.

Such a functional block diagram is suitable for an individual compressor. If another fixed-speed compressor operates in parallel with it, the PID controller of the first compressor will not cope with a disturbance occurring at starts and shutdowns or loads and unloads. In other words, at the moments when such disturbances occur, the PID controller should be influenced by shutting off I and D components or by releasing part of the controller output signal which was input by these components. This function is obviously to be performed by a special master controller, which will implement general control of the multi-compressor system. 


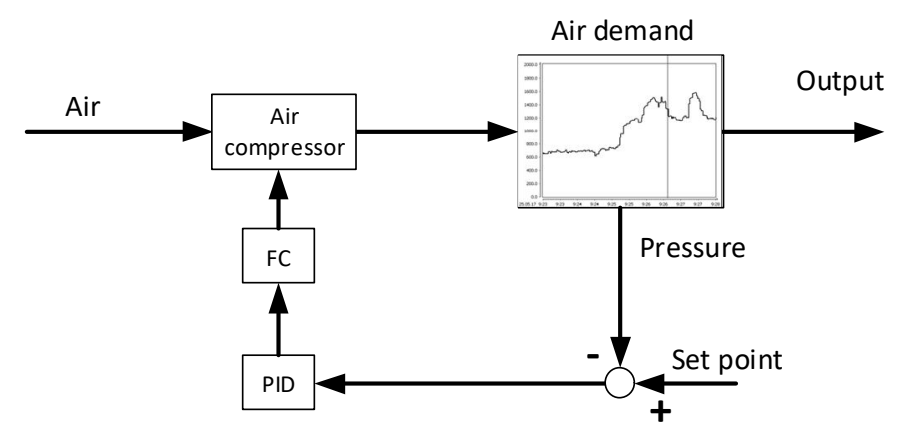

Fig.4. Functional block diagram for regulating the pressure by changing the rotation speed of the variable-load compressor drive.

An example of significant pressure swings for the cascade fixed-speed compressors and operation of the variable-load compressor with the maximum productivity is shown in Fig. 5.

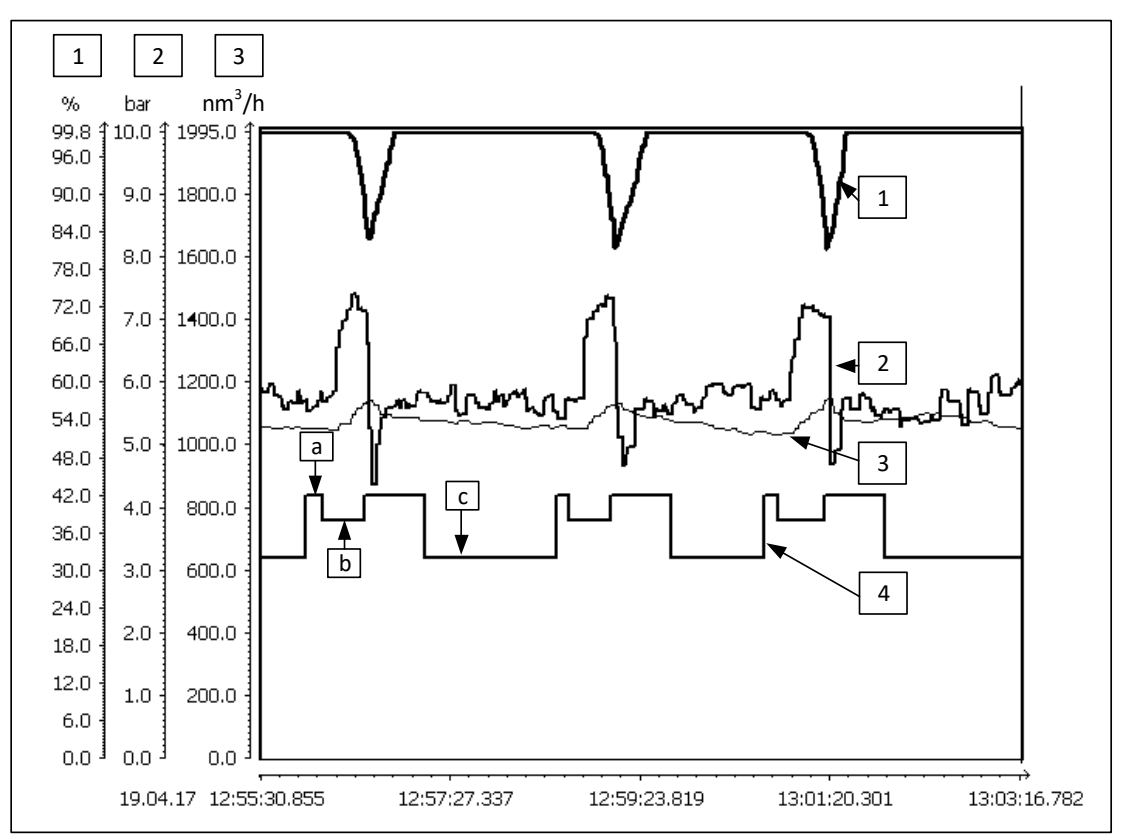

Fig.5. Historical trend of the multi-compressor system operation with a PID-controller in the variable-load compressor control system: 1 - set-point to the frequency converter from the PID-controller output, \% (the compressor productivity is 1175 $\mathrm{NM}^{3} / \mathrm{hr}$ ); 2 - air flow-rate at normal conditions, $\mathrm{m}^{3} / \mathrm{hr}$. (measured by the differential pressure method); 3 - pressure downstream of the filter, bar; 4 - functional block diagram of the fixed-load compressor ( $\mathrm{a}$ - unload mode, $\mathrm{b}$ - load mode, $\mathrm{c}$ - standby mode).

This historical trend shows that during the operation of the multi-compressor system there was a control gap. It consists in the fact that the variable-load compressor cannot produce an on-time response to the disturbance that arises when starting a fixed-load compressor. Apparently, in this control system it would be better and more efficient if the fixed-load compressor operated in the base load mode, and the variable-load compressor responded to all these relatively small surges in the flow-rate. In order to achieve this, the variable-load compressor control algorithm should be improved to incorporate specific features for the moments of starts and shutdowns of the fixed-load compressor.

In [4] it is proposed that the integral component of the controller should be changed depending on the value of the parameter being regulated. It is not clear, however, how this is to be done, as such controllers have variable structure and variable parameters. There are strict rules for the change of their structure and parameters; for instance, the gain factor or the integral controller can be changed only when the mismatching error signal crosses zero. 
Otherwise, this will be equivalent to causing a step disturbance and will put the system into the oscillatory mode of operation.

In $[1,5]$ the authors propose applying fuzzy logic for changing PID controller parameters depending on the pressure in the system and the speed of its variation. However, any controller supposed to implement fuzzy logic is itself a controller with a variable structure and parameters. All the above limitations hold true for this implementation, too. Similar algorithms are proposed for compressor systems consisting of one unit, but there are no cases of their practical implementation and use in industrial environments.

Obviously, for the multi-compressor system control in conditions of significant air flow-rate variation, control algorithms have to be quite sophisticated with strict rules for the change of the productivity of variable-load compressors, order of starting and shutting down fixed-load units and control of load and unload modes. Undoubtedly, as new auxiliary anticipatory signals are eventually introduced, researchers will work towards refining them.

\section{Defining the requirements to developing a control algorithm for a multi-compressor system}

When building the multi-compressor control systems using programmable logic controllers, the following points should be taken into consideration:

1) the control algorithm must have a variable structure and variable parameters;

2) the main algorithm is to be implemented on a programmable logic controller - the master; the local controllers must be configured in such a way so that the main algorithm implementation is not interfered with;

3) the start time of the fixed-load compressor is determined experimentally;

4) it is necessary to determine the time during which the compressor can work in the unload mode and the time needed for transition into the load mode;

5) it is necessary to find out the limitations on the minimum permissible rotation speed of the compressor drive, at which the cooling and lubrication modes are not disturbed;

6) it is advisable to expand the range of frequency variation of the power consumed by the compressor drive for drives up to $55-60 \mathrm{~Hz}$;

7) the compressed air pressure at the receiver output downstream of the system is to be considered the main signal for the control system operation;

8) the compressed air flow-rate at the system output is to be used as an auxiliary signal.

Our study showed that it is most advisable that the auxiliary anticipatory signal on air flow-rate change should be obtained when measuring the compressed air flow-rate using the differential pressure method. The practically implemented flow meter for the multi-compressor system is shown in Fig. 6. It is an all-welded single unit to which a differential manometer with a valve device assembly is connected.

Its major advantage is the high operation speed, which can be increased even more by using a differential manometer with an analogue conversion circuit. For most intelligent differential manometers, the time constant is $1 \mathrm{~s}$. The differential pressure flow meter is designed for the minimum possible pressure drop in order to minimize the pressure losses at the primary device. Thereat, the limitations stipulated by the rules for calculating standard primary devices can be dismissed here [6], as the air metering is technological, and a more important use of the flow meter is the formation of the anticipated signal on air flow-rate for the multi-compressor control system. 


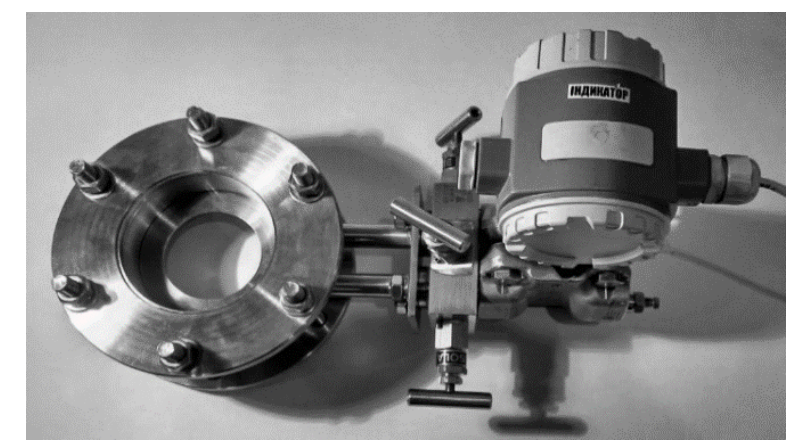

Fig.6. General view of the flow meter for measuring the compressed air flow-rate in the pipeline downstream of the multi-compressor system reciever.

The drawback of the method is the limited range of flow-rate measurement. Thermal flow meters which implement the hot-wire method feature a much wider measurement range but a lower speed of operation. The measurement range for the air flow-rate can be extended to include lower values, and the anticipatory signal can be respectively obtained at lower values of the flow-rate by using two differential manometers, as shown in Fig. 7.

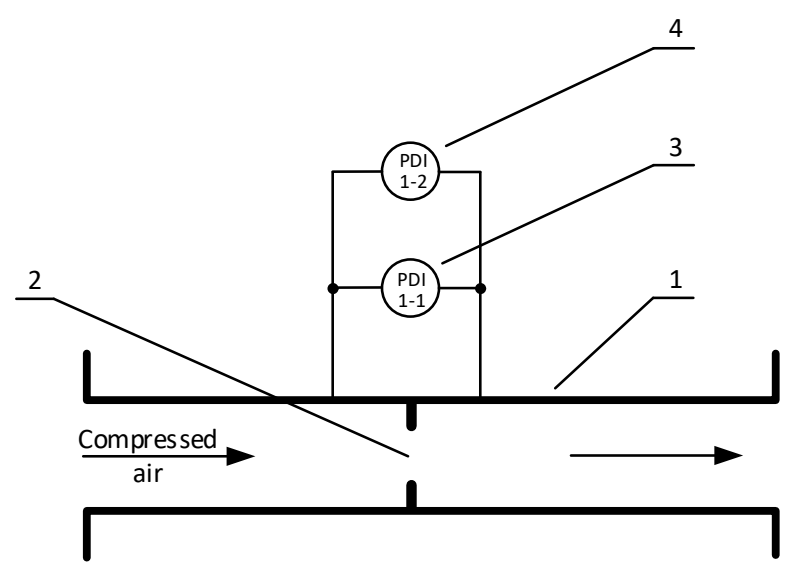

Fig.7. Functional diagram of the compressed air differential pressure flow meter with using two differential manometers: 1 - pipeline; 2 - primary device; 3 - main differential manometer; 4 - auxiliary differential manometer.

In this diagram, the auxiliary manometer is directly connected to the drains of the main manometer and is in the overload operation mode most of the time. The use of the compressed air flow meter allows obtaining an auxiliary anticipatory signal on the flow-rate variation.

\section{Development and study of the functional block diagram of the multi-compressor control system using a programmable logic controller}

Taking into account the outcomes of the previous studies, the functional block diagram of the multi-compressor control system was developed, in which the programmable logic controller functions as the master, and the local controllers of the control systems of the individual compressors are configured with maximum adaptation as the master's slaves. The diagram is shown in Fig. 8.

The two compressors operate in the fixed-speed mode, while the motor of the third compressor unit is powered from the frequency converter. The system uses two informative signals - the pressure in the pipeline downstream of the receiver and the air flow-rate in the pipeline downstream of the receiver. 


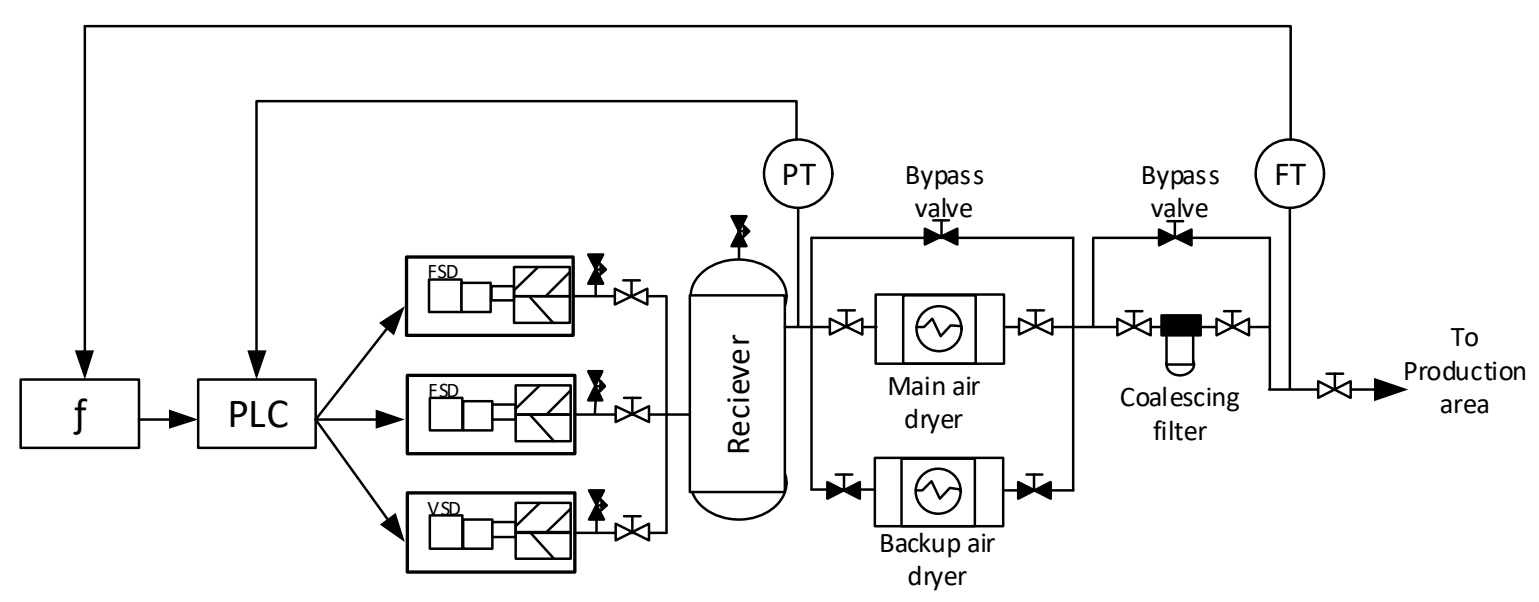

Fig.8. Functional block diagram of the multi-compressor control system using the master controller and auxiliary feedback on the flow-rate: FT - differential pressure flow meter; PT - pressure sensor;

PLC - programmable logic controller; $f(\mathrm{x})$-flow signal transfer function.

The developed system was implemented at Carlsberg Ukraine PJSC, Lviv Brewery and was studied with two operation algorithms. The first algorithm did not use the informative signal on the air flow-rate. The time histories of the control system operation reflected the air pressure surges at the outlet of the multi-compressor system, and one of them has been already presented (see Fig. 5 above).

The second, improved algorithm of the multi-compressor control system used the air flow-rate signal, and an example of the time histories of the multi-compressor system operation according to this algorithm is shown in Fig. 9.

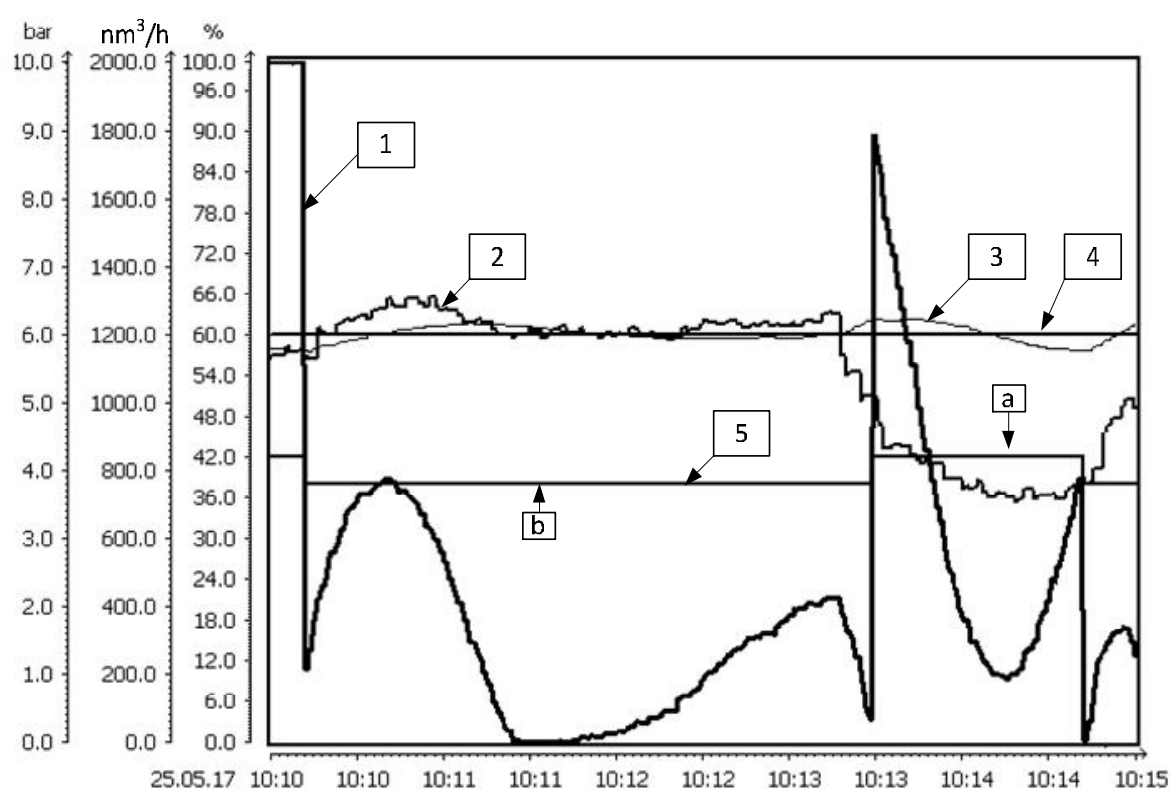

Fig.9. Historical trend of the multi-compressor system operation using a programmable logic controller in the control system and introducing an auxiliary flow-rate feedback:

1 - set-point to the frequency controller from the PID-controller output, \% (the compressor productivity is $1175 \mathrm{~nm}^{3} / \mathrm{h}$ );

2 - air flow-rate at normal conditions, $\mathrm{m}^{3} / \mathrm{hr}$. (measured by the differential pressure method);

3 - pressure downstream of the receiver, bar; 4 - pressure set-point downstream of the receiver, bar; 5 - functional block diagram of the fixed-load compressor ( $\mathrm{a}$ - unload mode, $\mathrm{b}$ - load mode). 
This historical trend confirms that the introduction of the auxiliary feedback on the air flow-rate and general control of the multi-compressor system by the master controller ensure more accurate maintenance of the air pressure at the system output at a variable air consumption. Therefore, the second algorithm is better than the first one. Further study can focus on improving the modes of control of starts and shutdowns of the fixed-speed compressors and the modes of switching the compressors from the unload status to the load one.

\title{
7. Conclusion
}

The study resulted in formulating the main principles of building the control algorithms for medium-power multi-compressor systems. The modes of compressed air consumption by a brewery were studied. The operation trends of the multi-compressor control system were explored applying the two developed algorithms. The differential pressure flow meter was implemented, the signal from which makes it possible to devise more efficient control algorithms for the multi-compressor system.

\section{References}

[1] Chris Schmidt, Kelly Kissock (2005) Modeling and Simulation of Air Compressor Energy Use. ACEEE Summer Study on Energy Efficiency in Industry,July 19-22, 131 - 142p. https://aceee.org/files/proceedings/2005/data/index.htm.

[2] Energy Efficiency of Compressed Air Systems/ Smaeil Mousavi,Sami Kara, Bernard Kornfeld// 21 st CIRP Conference on Life Cycle Engineering/ Procedia CIRP, 2014. - 313-318 p.

[3] Neil Mehltretter(2012), “Proper Application of Variable Speed Compressors”. World Energy Engineering Congress, 2012 ,999-1015 p.

[4] Chunyue PAN(2017) Air Compressor Pressure Control System Based On Gearshift Integral PID Controller. MATEC Web of Conferences 139, 00199 (2017) ICMITE 2017 DOI: 10.1051/matecconf/201713900199

[5] J. Javadi Moghaddam, M. Madani (2010) A decoupled adaptive neuro-fuzzy sliding mode control system to control rotating stall and surge in axial compressors Expert Systems with Applications Volume 38, Issue 4, April 2011, Pages 4490-449 https://doi.org/10.1016/j.eswa.2010.09.122.

[6] Pistun, Y.; Lesovoi, L.; Matiko, F.; Markovskyi, D \& Lesovoi, R. (2007) "RASKHOD-RU” CAD computer programme. Manual. Publishing House of "Institute of Energy Audit and Energy Carrier Accounting” CJSC, Lviv - 128 p. (in Russian)

[7] US Department of Energy. Improving compressed system performance: a sourcebook for industry. - Washington : U.S. Department of EERE, 2003. - 128 p.

[8] Brian S. Elliott. (2006) Compressed Air Operations Manual. - McGraw-Hill Education, 2006 - 407 p. ISBN: 978-0-07-149184-6 MHID: 0$07-149184-8$.

[9] https://www.nrcan.gc.ca/energy/products/reference/14970\#mb-pnl

[10] http://okolje.arso.gov.si/ippc/uploads/File/Compressed_air_en.pdf [09.04.2019]

[11] https:/www.airbestpractices.com/system-assessments/compressor-controls/central-monitoring-and-control-multiple-air-compressors

\section{Вибір структурної схеми системи керування мультикомпресорною установкою для одержання стисненого повітря}

\author{
Роман Кокошко, Олександр Кріль, Богдан Кріль \\ Національний університет «Львівська політехніка», вул. С. Бандери. 12, м. Львів, 79013, Україна
}

\section{Анотація}

Системи для одержання стисненого повітря є необхідною складовою більшості підприємств, і вони $є$ одним з найбільших споживачів електричної енергії. Дослідження перехідних процесів роботи цих установок $\epsilon$ необхідною передумовою при створенні нових більш ефективних алгоритмів роботи систем керування мультикомпресорними установками. Результати розробки та дослідження алгоритмів роботи систем керування мультикомпресорними установками розглядаються в цій статті. Пропонується основні рішення по 
вмиканню і вимиканню окремих агрегатів та зміні продуктивності реалізувати на вільнопрограмованому логічному контролері, який буде виконувати функцію мастера для локальних контролерів окремих компресорних агрегатів. Розроблений та реалізований швидкодіючий витратомір для вимірювання витрати споживаного повітря за методом змінного перепаду тиску, який застосовано як додатковий інформативний сигнал.

Ключові слова: мультикомпресорна установка; компресорний агрегат; стиснене повітря; вільнопрограмований логічний контролер; частотний привід. 